\title{
Kuat Tekan dan Tarik Belah Beton Serat Menggunakan Aggregat Ringan
}

\author{
(Compressive and Splitting Tensile Strength of Fiber Concrete with Lightweight Aggregate)
}

\author{
As' At Pujianto, Restu FAiZAh, DOdy Agusto Wijaya, JunAidi AbDURAJAK, HAKAS \\ PRAYUDA, HENDY WIJAYA
}

\begin{abstract}
ABSTRAK
Beton adalah material untuk infrastruktur sipil yang sangat sering ditemukan dan digunakan di Indonesia. Beton memiliki berbagai kelebihan di antaranya ekonomis, tahan lama, ketahanan terhadap api yang tinggi dan kemudahan untuk mendapatkan bahan penyusunnya. Beton memiliki berat lebih kurang $2400 \mathrm{~kg} / \mathrm{m}^{3}$, berat sendiri beton yang cukup tinggi merupakan salah satu kelemahan yang dimiliki beton. Tujuan dari penelitian ini adalah untuk menginvestigasi sifat dasar mekanik beton ringan yang dikombinasikan dengan fiber. Batu apung digunakan pada penelitian ini sebagai agregat kasar sehingga berat jenis dari beton menjadi berkurang. Selain itu, untuk meningkatkan daktilitas beton digunakan dua jenis serat sebagai material tambahan. Serat buatan yang digunakan berupa glass fiber dan steel fiber dengan jumlahnya divariasikan dari $0 \% ; 0,5 \% ; 0,75 \%$ dan $1,0 \%$ dari total berat binder. Beberapa pengujian yang dilakukan pada studi ini yaitu memeriksa sifat beton segar dan beton yang telah mengeras. Pengujian slump dilakukan untuk memeriksa tingkat workabilitas beton segar sedangkan kuat tekan dan kuat tarik belah pada umur beton 28 hari dengan benda uji berbentuk silinder digunakan untuk menginvestigasi sifat beton yang telah mengeras. Hasil pemeriksaan beton segar menunjukkan bahwa penambahan jumlah serat yang tinggi menghasilkan workabilitas yang rendah. Sedangkan sifat beton keras menunjukkan bahwa baik kuat tekan maupun kuat tarik belah dengan jumlah serat yang tinggi mengalami peningkatan dibandingkan dengan beton normal.
\end{abstract}

Kata kunci: Beton ringan, Beton serat, Kuat tekan, Kuat Tarik belah.

\section{ABSTRACT}

Concrete is commonly used as civil infrastructure material in Indonesia. Concrete has many advantages, including economic, durable, high fire resistance, and the availability of raw materials. The mass density of concrete is $2400 \mathrm{~kg} / \mathrm{m}^{3}$, and this is one of the disadvantages of concrete. The purpose of this study is to investigate the basic mechanical properties of lightweight concrete combined with fiber. Pumice is used in this study as coarse aggregate so that the mass density of concrete will be decreased. Besides, to improve the ductility of concrete, two types of fiber are applied as supplementary materials. Two different types of artificial fiber are used: glass fiber and steel fiber; the fiber varies from $0 ; 0.5 ; 0.75$ and $1 \%$ of total binder weight. Several tests are conducted in this study to investigate the fresh and hardened properties of lightweight concrete. A slump test is applied to check the workability of fresh concrete, while compressive and splitting tensile strength with cylinder specimens is applied to investigate the hardened properties. The fresh properties results show that concrete with a high amount of fiber produces low workability. On the other hand, the hardened properties results show that the compressive and splitting tensile strength with a high amount of fiber increases compared to standard concrete.

Keywords: Lightweight Concrete, Fiber Concrete, Compressive Strength, Splitting Tensile Strength 


\section{PENDAHULUAN}

Beton merupakan material yang mudah dijumpai sebagai salah satu material konstruksi di Indonesia. Hal tersebut dikarenakan bahan penyusun beton yang sangat mudah ditemui diberbagai daerah dengan tingkat harga yang relative lebih rendah dibandingkan dengan material infrastruktur sipil lainnya. Penggunaan beton sebagai material konstuksi infrastruktur memiliki beberapa keuntungan di antaranya kuat tekan yang relatif tinggi, mudah dibentuk, ekomonis, tahan lama dan memiliki ketahanan yang cenderung lebih baik untuk diberbagai kondisi lingkungan.

Namun demikian, beton juga memiliki beberapa kelemahan yang menyebabkan umur layanannya dapat berkurang. Beton memiliki sifat getas yang menyebabkan akan sangat mudah terjadi retak atau rusak apabila diberikan beban tarik. Apabila gaya tarik yang terjadi melebihi kapasitasnya, retak pada beton akan terjadi. Apabila retak ini terus menerus dibiarkan, akan menyebabkan penurunan daya tahan bahkan dapat menyebabkan korosi pada tulangan di dalamnya apabila udara dan air telah bereaksi. Kelemahan beton tersebut tentunya menjadi fokus utama peneliti untuk meningkatkan kapasitas tarik pada beton.

Pemanfaatan serat sebagai bahan tambahan pada beton dalam usaha meningkatkan kapasitas tariknya bukanlah suatu hal yang baru. Pada umumnya, serat alami dan serat buatan merupakan jenis serat yang seringkali digunakan dalam pembuatan beton. Serat alami biasanya berasal dari bahan bahan alam seperti serat pohon pisang, serat daun nanas dan berbagai limbah lainnya. Sedangkan serat buatan seperti serat baja, serat aramid, serat kaca dan lain sebagainya.

Beberapa penelitian mengenai penambahan serat baja telah ditemukan. Thomas dan Ramaswamy (2007) memeriksa sifat mekanik beton dengan material serat baja untuk pembuatan beton dengan mutu tinggi. Hasil penelitian yang diperoleh menunjukkan bahwa serat berkonstribusi cukup baik dalam meningkatkan sifat mekanik beton mutu tinggi. Hal serupa juga telah diteliti oleh Song dan Hwang (2004) yang menjelaskan bahwa penambahan serat pada beton dapat membantu meningkatkan sifat mekanik beton yaitu kuat tekan dan kuat tarik belah. Prayuda dkk,
(2020) melakukan penelitian mengenai serat baja pada beton memadat sendiri, hasil pengujian menunjukkan bahwa serat cukup efektif dalam meingkatkan sifat beton yang sudah mengeras, namun demikian penambahan serat pada beton dapat mengurangi kinerja beton pada saat masih segar atau mengurangi workabilitasnya.

Selain penambahan serat baja, pada penelitian ini juga menggunakan alkali resistance glass fiber. Pratiwi dkk, (2016) dan Ikhsan dkk, (2016) melakukan penelitian mengenai penambahan pecahan kaca dan limbah fiber optik sebagai bahan tambah pada pembuatan beton mutu normal. Hasil menunjukkan bahwa kuat tekan tertinggi dihasilkan pada saat menggunakan serat sebesar $0,15 \%$ dari berat beton. Penelitian lainnya mengenai alkali resistance glass fiber juga dilakukan oleh Mirza dan Soroushian (2002) serta Ghugal dan Deshmukh (2006). Dari kedua penelitian tersebut menjelaskan bahwa kekuatan beton mengalami peningkatan yang cukup signifikan dengan adanya penambahan serat di dalam beton baik beton normal maupun beton ringan.

Selain permasalahan terhadap kuat tarik rendah, beton juga memiliki kendala terhadap berat sendiri yang cukup besar. Massa jenis beton normal berkisar antara $2300 \mathrm{~kg} / \mathrm{m}^{3}$ sampai $2400 \mathrm{~kg} / \mathrm{m}^{3}$. Kondisi beton tersebut tidak cukup menguntungkan untuk beberapa faktor khususnya untuk konstruksi tahan gempa. Pada penelitian ini menggunakan batu apung yang bertujuan untuk mengurangi berat sendiri beton.

Penggunaan batu apung sebagai material penyusun beton dipercaya dapat mengurangi berat beton. Hossain dan Lachemi (2007) meneliti mengenai pemanfaatan batu apung yang berasal dari hasil erupsi gunung berapi. Hasil pengujian menunjukkan bahwa pemanfaatan batu apung sebagai material penyusun beton mampu memenuhi persyaratan standar kekuatan beton dan memenuhi syarat durabilitasnya. Hal yang sama juga telah ditemukan pada penelitian yang dilakukan oleh Binici dkk (2008) meneliti pengaruh penambahan patu apung pada beton untuk wilayah yang dekat dengan air laut.

Di Indonesia sendiri, penelitian mengenai pemanfaatan batu apung juga sudah dilakukan oleh beberapa peneliti. Rahamudin dkk, (2016) menggunakan batu apung sebagai pengganti aggregat kasar menjelaskan bahwa dengan 
pemanfaatan batu apung ini dapat mengurangi berat beton menjadi $1440 \mathrm{~kg} / \mathrm{m}^{3}$. Hal serupa juga dilaporkan oleh Miswar (2020) yang menjelaskan bahwa pemanfaatan batu apung menghasilkan berat beron berkisar antara 864 $\mathrm{kg} / \mathrm{m}^{3}$ sampai $1404 \mathrm{~kg} / \mathrm{m}^{3}$.

Penelitian ini bertujuan untuk memeriksa sifat beton dengan menggunakan agregat ringan batu apung serat dengan variasi tambahan serat baja dan serat kaca. Melalui penelitian ini diharapkan dapat menghasilkan data karakteristik beton khususnya kuat tekan beton dan kuat tarik belah beton ringan berserat pada saat beton berumur 28 hari. Pengujian yang dilakukan pada penelitian ini terdiri dari pemeriksaan sifat segar beton melalui pengujian slump. Selain itu, dilakukan juga pemeriksaan berat jenis beton untuk mengetahui pengaruh dari aggregat kasar dan penambahan serat terhadap berat beton.

\section{METODE PENELITIAN}

Material penyusun beton yang digunakan pada penelitian ini terdiri dari semen Portland tipe 1 sebagai binder. Agregat kasar berupa batu apung dengan ukuran maksimal $25 \mathrm{~mm}$ yang berasal dari Mataram, Nusa Tenggara Barat. Agregat halus berupa pasir merapi dari Sleman, Yogyakarta. Adapun hasil pemeriksaan sifat mekanik agregat halus dan agregat kasar dapat dilihat pada Tabel 1 dan Gambar 1 berupa hasil pengujian gradasi agregat halus. Sedangkan serat yang digunakan terdiri dari dua jenis yaitu serat baja dan alkali resistance glass fiber dengan ukuran panjang $50 \mathrm{~mm}$.

Campuran proporsi setiap variasi beton dapat dilihat pada Tabel 2. Pada proses penelitian ini digunakan kode spesimen $\mathrm{BN}$ yang artinya beton normal tanpa campuran serat, sedangkan kode spesimen SB merupakan spesimen dengan bahan tambah serat baja dan SK dengan menggunakan bahan tambah alkali resistance glass fiber.

Pengujian yang dilakukan pada penelitian ini terdiri dari slump untuk beton segar untuk merekam data tingkat workabilitas beton segar. Sedangkan pemeriksaan sifat beton yang telah mengeras terdiri dari pengujian kuat tekan beton yang mengacu pada ASTM C38 (ASTM, 2019) dan kuat tarik belah beton yang mengacu pada ASTM 496 (ASTM, 2017). Benda uji untuk pengujian kuat tekan dan kuat tarik belah berbentuk silinder dengan diameter $150 \mathrm{~mm}$ dan tinggi $300 \mathrm{~mm}$. Pengujian dilakukan pada saat beton berumur 28 hari. Selama masa tunggu pengujian, beton direndam didalam air untuk menyempurnakan proses hidrasi semen.

TABEL 1. Sifat Mekanik Agregat Halus dan Agregat Kasar

\begin{tabular}{lcc}
\hline \multicolumn{1}{l}{ Pengujian } & Aggregat Halus & Agregat Kasar \\
\hline Kadar Air (\%) & 2,53 & 26,03 \\
Berat Jenis & 2,66 & 1,55 \\
Penyerapan Air (\%) & 11,11 & 52,25 \\
Berat Satuan (g/cm $\left.{ }^{3}\right)$ & 1,425 & 0,622 \\
Kadar Lumpur $(\%)$ & 2,73 & 0,93 \\
Keausan $(\%)$ & - & $36,50 \%$ \\
\end{tabular}




\section{Gradasi Agregat Halus}

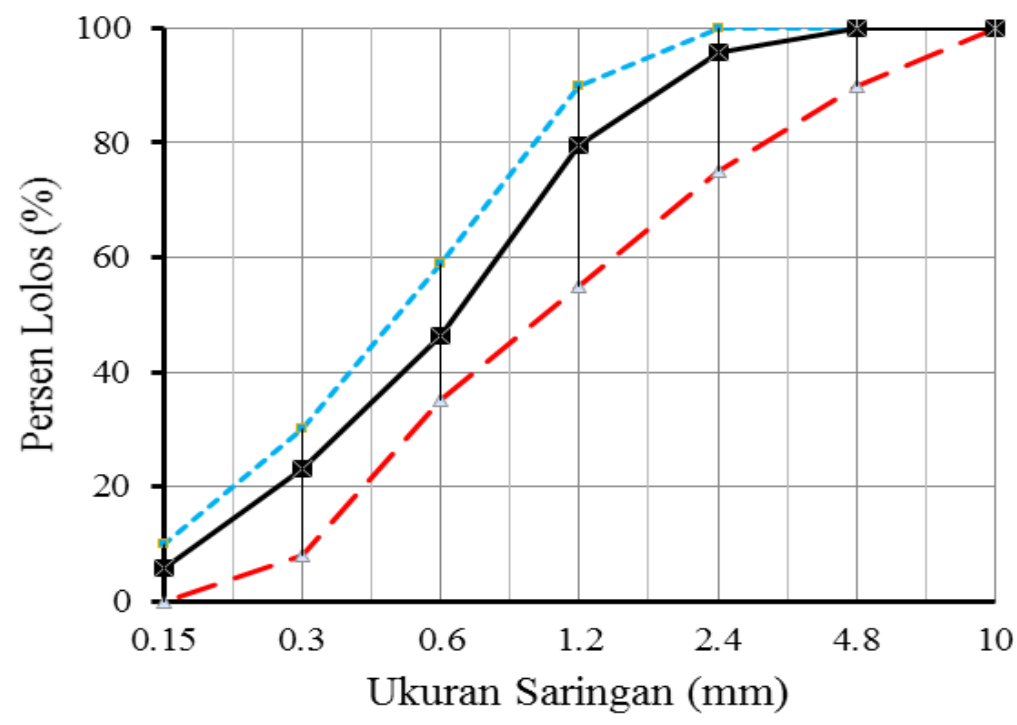

$\longrightarrow \triangle$ Agar kasar min - - - - Agak kasar max $\longrightarrow \longleftarrow$ Hasil Pengujian

GAMBAR 1. Gradasi Agregat Halus

TABEL 2. Proporsi Campuran Beton untuk $1 \mathrm{~m}^{3}$

\begin{tabular}{cccccccc}
\hline \multirow{2}{*}{$\begin{array}{c}\text { Kode } \\
\text { Spesimen }\end{array}$} & Semen & Air & $\begin{array}{c}\text { Agregat } \\
\text { Kasar }\end{array}$ & $\begin{array}{c}\text { Agregat } \\
\text { Halus }\end{array}$ & $\begin{array}{c}\text { Serat } \\
\text { Baja }\end{array}$ & $\begin{array}{c}\text { Serat } \\
\text { Kaca }\end{array}$ & FAS \\
\hline & & & & & & & \\
BN & 200,71 & 99,84 & 394,17 & 252,00 & - & - & 0,50 \\
SB0.50 & 200,71 & 99,84 & 394,17 & 252,00 & 1,00 & - & 0,50 \\
SB0.75 & 200,71 & 99,84 & 394,17 & 252,00 & 1,51 & - & 0,50 \\
SB1.00 & 200,71 & 99,84 & 394,17 & 252,00 & 2,01 & - & 0,50 \\
SK0.50 & 200,71 & 99,84 & 394,17 & 252,00 & - & 1,00 & 0,50 \\
SK0.75 & 200,71 & 99,84 & 394,17 & 252,00 & - & 1,51 & 0,50 \\
SK1.00 & 200,71 & 99,84 & 394,17 & 252,00 & - & 2,01 & 0,50 \\
\hline
\end{tabular}

\section{HASIL DAN PEMBAHASAN}

Hasil pengujian slump pada beton segar dapat dilihat pada Gambar 2. Benda uji beton normal tanpa penambahan serat terlihat bahwa slump yang diperoleh yaitu $19 \mathrm{~cm}$. sedangkan beton dengan penambahan serat, baik serat baja maupun serat kaca menunjukkan penurunan nilai slump. Hal ini mengindikasi bahwa penambahan serat dapat mengurangi workabilitas beton sedar. Penambahan serat baja pada beton menunjukkan kisaran nilai slump antara 15-17 cm, sedangkan penambahan serat kaca penunjukkan nilai slump antara $13-15 \mathrm{~cm}$. Meskipun nilai slump mengalami penurunan, pada penelitian ini menunjukkan hasil dengan penggunaan jumlah serat maksimal sebesar $1 \%$ dari total berat binder masih memenuhi standar nilai slump beton segar untuk bangunan gedung. 


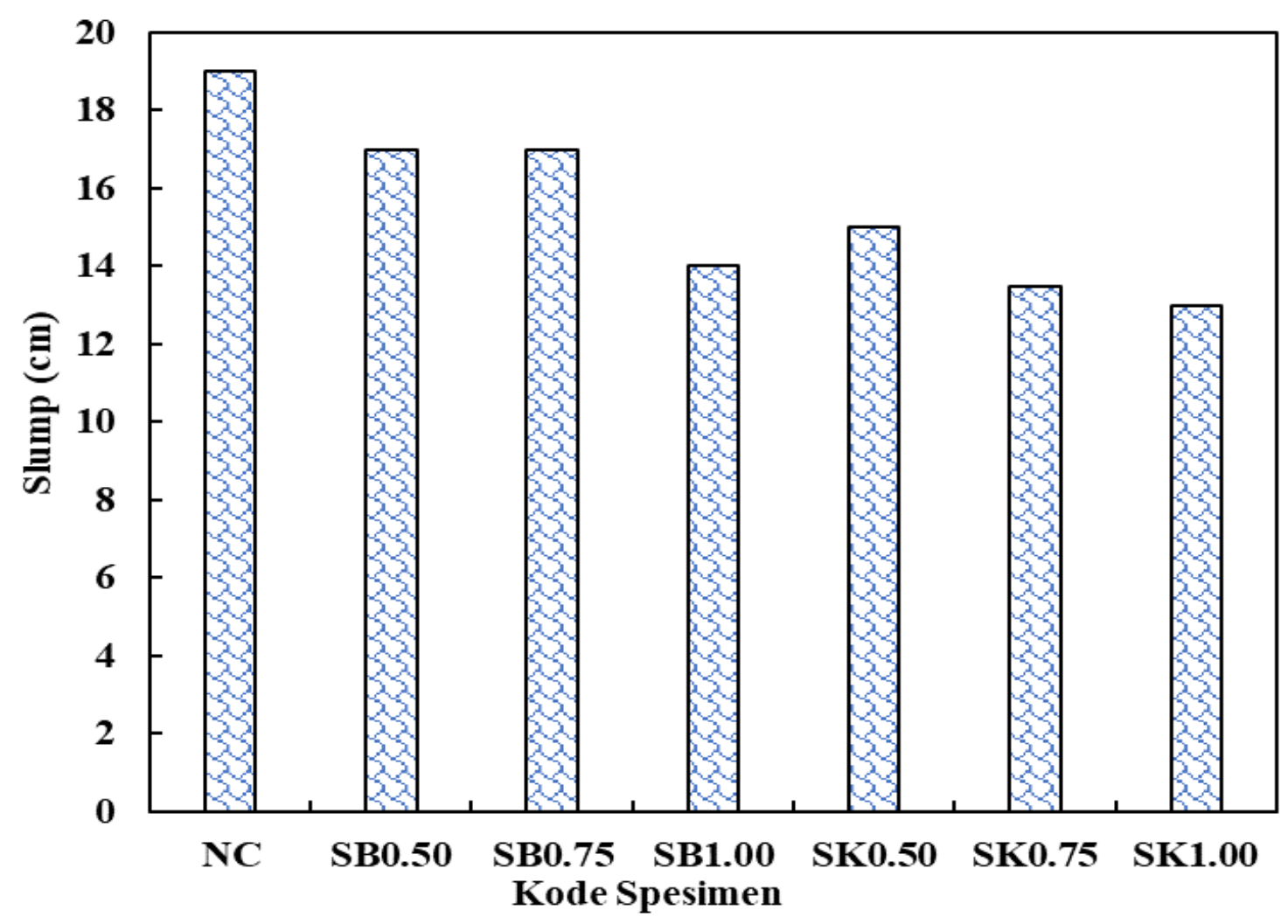

GAMBAR 2. Hasil Pengujian Slump

Pengujian kuat tekan dilakukan pada saat beton berumur 28 hari dapat ditemukan pada Gambar 3. Benda uji direndam didalam air terlebih dahulu sebelum dilakukan pengujian. Pada masing-masing variasi dilakukan pengujian sebanyak 3 benda uji yang kemudian hasil kuat tekan diambil dari ratarata masing-masing variasi.

Pengujian kuat tekan beton normal memperoleh hasil sebesar 7,21 MPa. Sedangkan, variasi benda uji dengan penambahan serat baja diperoleh kuat tekan 9,11 MPa untuk serat 0,5\%, kuat tekan 9,27 MPa untuk serat $0,75 \%$, sedangkan dengan penambahan serat baja 1.0\% memperoleh kuat tekan sebesar 10,12 MPa. Dari hasil pengujian beton dengan tambahan serat baja menunjukkan bahwa semakin bertambah serat yang digunakan maka kuat tekan yang diperoleh juga meningkat. Sedangkan pada beton dengan tambahan serat kaca memperoleh kuat tekan sebesar 7,37 $\mathrm{MPa}$ untuk penambahan serat $0,5 \%, 9,75 \mathrm{MPa}$ untuk penambahan serat $0,75 \%$ dan 11,22 MPa untuk penambahan serat sebesar $1,0 \%$. Hasil pengujian ini juga menunjukkan bahwa semakin meningkat kadar serat yang digunakan maka kuat tekan yang diperoleh pada saat beton berumur 28 hari juga semakin tinggi.

Hasil pengujian kuat tekan beton dengan tambahan serat mengalami peningkatan dikarenakan serat dapat membantu memperkuat ikatan antar penyusun beton. apabila diberikan gaya tekan, serat yang terdapat didalam beton bekerja sehingga menyebabkan terjadinya peningkatan ketahanan dalam menahan beban tekan. Dari pengujian kuat tekan pada kedua jenis serat ini data disimpulkan bahwa hasil pengujian tidak memiliki perpedaan yang cukup signifikan. Sehingga disimpulkan bahwa perbedaan jenis serat baik serat baca maupun serat baja memiliki karakteristik yang sama apabila dilihat dari hasil pengujian kuat tekannya. 


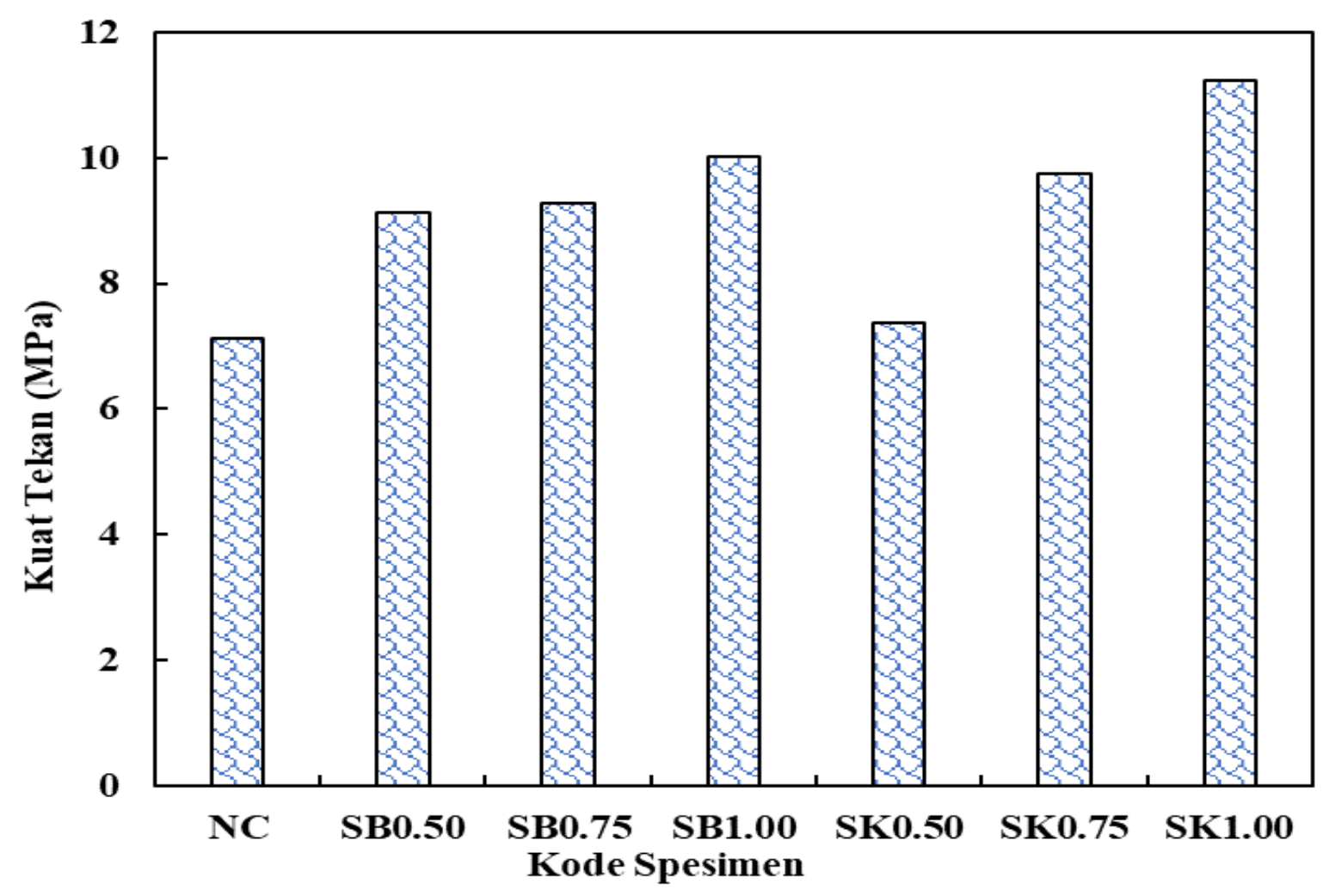

GAMBAR 3. Kuat Tekan Beton Umur 28 Hari untuk Beton Normal dan Beton Berserat.

Hasil pemeriksaan kuat tarik belah untuk beton normal tanpa serat dan beton berserat dapat ditemukan pada Gambar 4. Standar perawatan dan umur pengujian tarik belah beton sama dengan pengujian tekan serta dimensi benda uji yang digunakan juga sama.

Pengujian kuat tarik belah pada beton normal tanpa serat dilakukan saat berumur 28 hari yaitu sebesar 2,12 MPa. Sedangkan pada beton serat baja memperoleh kuat tarik sebesar 3,77 MPa untuk penambahan serat $0,5 \%$, dengan penambahan serat $0,75 \%$ memperoleh kuat tarik belah sebesar 3,87 $\mathrm{MPa}$ dan untuk penambahan serat sebesar 1,0\% memperoleh kuat tarik belah sebesar 4,21 $\mathrm{MPa}$. Peningkatan yang cukup signifikan terlihat antara beton tanpa menggunakan dengan yang menggunakan serat $0,5 \%$. Sedangkan pada pengujian kuat tarik belah pada beton dengan tambahan serat kaca memperoleh hasil 3,02 MPa untuk tambahan serat sebesar 0,5\%, 3,88 MPa untuk tambahan serat $0,75 \%$ dan kuat tarik belah sebesat 4,31 untuk tambahan serat sebesar $1,0 \%$.

Hasil pengujian menunjukkan bahwa dengan penambahan serat menghasilkan peningkatan kuat tarik belah yang cukup signifikan. Hal ini membuktikan bahwa penambahan serat dapat meningkatkan kuat tarik dan kuat tekan beton sehingga mampu membantu meningkatkan daya tahan beton khususnya dalam menahan beban tarik. Selain itu, apabila dibandingkan hasil kuat tarik belah andata kedua jenis serat yang digunakan, ahil pengujian menunjukkan perbedaan hasil yang tidak terlalu jaub antara beton dengan serat baja terhadap beton dengan serat kaca. 


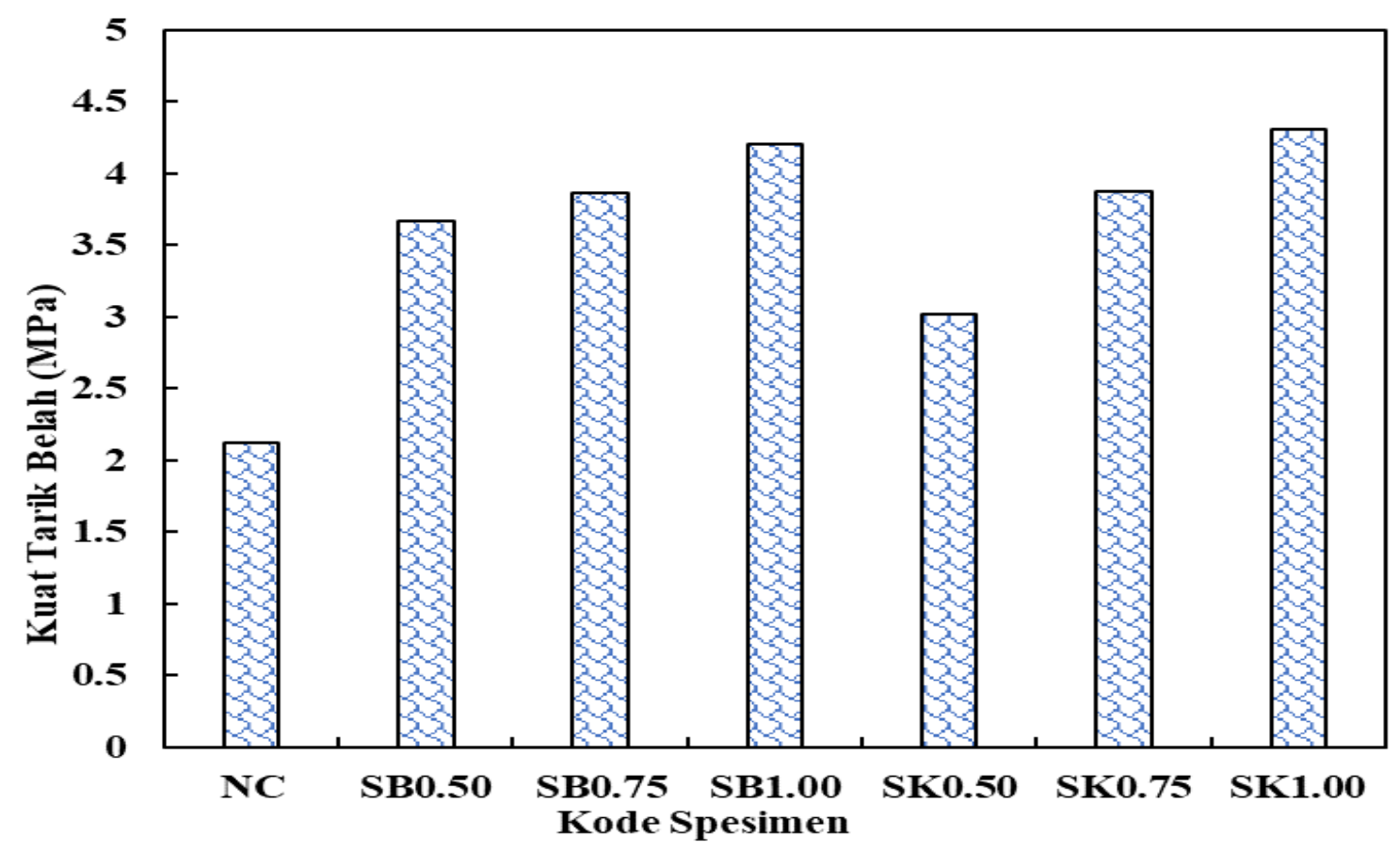

GAMBAR 4. Kuat Tarik Belah Beton Umur 28 Hari untuk Beton Tanpa dan Menggunakan Serat

Pemeriksaan berat satuan juga dilakukan untuk memeriksa pengaruh penambahan serat terhadap berat satuan beton pada saat berumur 28 hari. Beton normal tanpa serat memperoleh berat satuan sebesar 1610,06 $\mathrm{kg} / \mathrm{m}^{3}$. Sedangkan beton dengan tambahan serat baja $0,5 \%$ memperoleh berat satuan sebesar $1597,48 \mathrm{~kg} / \mathrm{m}^{3}$, dengan penambahan serat $0,75 \%$ memperoleh berat satuan sebesar $1616,35 \mathrm{~kg} / \mathrm{m} 3$ dan dengan penambahan serat $1,0 \%$ memperoleh berat satuan sebesar $1676,35 \mathrm{~kg} / \mathrm{m}^{3}$. Hasil pengujian menunjukkan bahwa semakin bertambah kadar serat yang digunakan, maka berat satuan yang digunakan juga meningkat. Namun demikian, peningkatan serat satuan yang dihasilkan tidak melebihi batas maksimal kategori beton ringan. Pada Gambar 5 juga menampilkan hasil pengujian berat satuan untuk beton dengan tambahan serat kaca. Dari hasil pengujian menunjukkan bahwa dengan tambahan serat sebesar 0,5\% memperoleh hasil berat satuan sebesar $1603,77 \mathrm{~kg} / \mathrm{m}^{3}$, sedangkan dengan penambahan serat sebesar $0,75 \%$ memperoleh nilai berat satuan sebesar 1679,24 $\mathrm{kg} / \mathrm{m}^{3}$ dan pada beton dengan tambahan serat kaca sebesar $1,0 \%$ memperoleh berat satuan sebesar $1710,69 \mathrm{~kg} / \mathrm{m}^{3}$.

Secara keseluruhan melalui hasil pengujian berat satuan dapat disimpulkan bahwa penambahan serat dapat meningkatkan berat satuan beton, berat satuan yang dihasilkan berkisar antara 1600 sampai $1700 \mathrm{~kg} / \mathrm{m}^{3}$. Hal ini penunjukkan bahwa berat satuan beton emngalami penurunan dibandingkan beton normal yang menggunakan agregat normal yaitu berkisar antara 2300 sampai $2400 \mathrm{~kg} / \mathrm{m}^{3}$. Selain itu, hasil pengujian ini menunjukkan bahwa seluruh variasi dapat dikategorikan beton ringan karena berat satuan yang dihasilkan tidak lebih dari $1800 \mathrm{~kg} / \mathrm{m}^{3}$. 


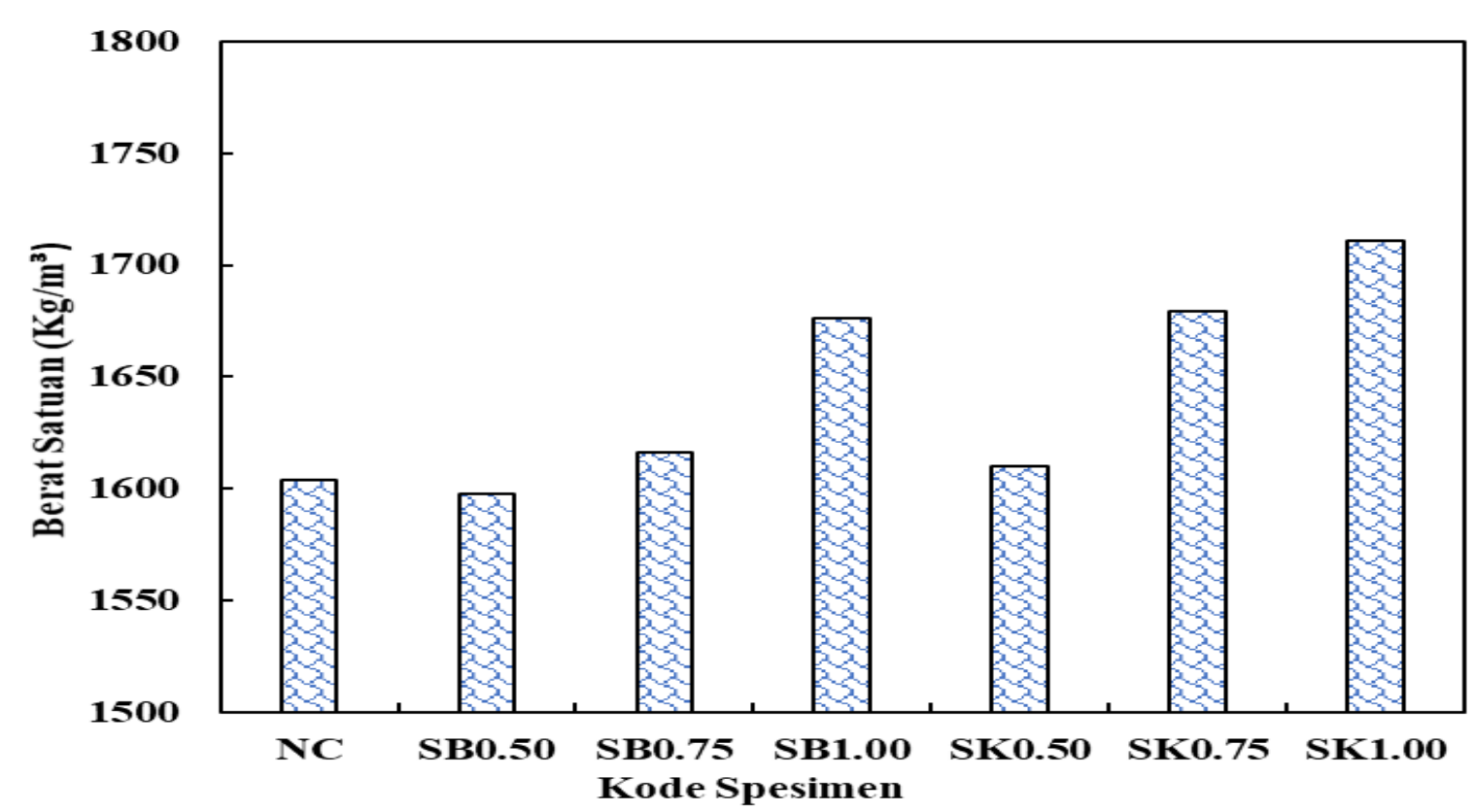

GAMBAR 5. Berat Satuan Beton Umur 28 Hari

\section{KESIMPULAN}

Hasil pemeriksaan beton segar baik dengan tambahan serat baja maupun serat kaca menunjukkan bahwa nilai workabilitas beton berkurang akibat dari penambahan serat. Namun demikian, terjadinya pengurangan workabilitas masih memenuhi standar yang berlaku untuk pekerjaan beton segar pada konstruksi sipil khususnya konstruksi gedung. Hasil pemeriksaan kuat tekan pada beton berumur 28 hari menunjukkan bahwa semakin bertambah kadar serat, maka kuat tekan yang dihasilkan juga semakin meningkat. Tidak terdapat perbedaan kuat tekan yang signifikan antara beton menggunakan serat baja maupun serat kaca sehingga dapat disimpulkan bahwa karakteristik kedua jenis serat ini terdapat kemiripan. Hasil pemeriksaan kuat tarik belah pada beton keras menunjukkan bahwa semakin bertambah jumlah serat yang digunakan, maka kuat tarik belah beton yang dihasilkan meningkat cukup tinggi. Hal ini menunjukkan bahwa penambahan serat cukup efektif dalam meningkatkan kuat tarik pada beton. Hasil pemeriksaan berat satuan menunjukkan bahwa semakin bertambah jumlah serat yang digunakan, maka berat satuan beton juga meningkat. Berat satuan yang dihasilkan antara $1600-1700 \mathrm{~kg} / \mathrm{m}^{3}$. hasil pengujian berat satuan ini menunjukkan bahwa beton masih dikaregorikan sebagai beton normal.

\section{DAFTAR PUSTAKA}

ASTM Internasional. (2019). C39/C39M-18: Standard Test Method for Compressive Strength of cylindrical Concrete Specimens, American Standards Testing Materials, West Con-shohocken, United States.

ASTM C496/ C496M -17, 2017. Standard Test Method for Splitting Tensile Strength of Cylindrical Concrete Specimens, ASTM International, West Conshohocken, PA.

Binici, H., Aksogan, O., Gorur, E. B., Kaplan, H., Bodur, M. N., 2008. Performance of ground blast furnace slag and ground basaltic pumice concrete against seawater attack, Construction and Building Materials, 22(7), 1515-1526. https://doi.org/10.1016/j.conbuildmat.20 07.03.024

Ghugal, Y. M., \& Deshmukh, S. B. (2006). Performance of Alkali-Resistant Glass Fiber Reinforced Concrete, Journal of Reinforced Plastics and Composites, 25(6), 617-630. https://doi.org/10.1177\%2F0731684405 058273

Hossain, K. M. A., \& Lachemi, M. (2007). Mixture design strength durability and 
fire resistance of lightweight pumice concrete, ACI Materials Journal, 104(5), 449-459. https://doi.org/10.1177\%2F0731684405 058273

Ikhsan, M. N., Prayuda, H., \& Saleh, F. (2016). Pengaruh penambahan pecahan kaca sebagai bahan pengganti aggregat halus dan penambahan fiber optik terhadap kuat tekan beton serat. Semesta Teknika, $\quad$ 19(2), 148-156. https://doi.org/10.18196/st.v19i2.2037

Mirza, F. A., \& Soroushian, P. (2002). Effects of alkasi-resistant glass fiber reinforcement on crack and temperature resistance of lightweight concrete, Cement and Concrete Composites, 24(2), 223-227. https://doi.org/10.1016/S09589465(01)00038-5

Miswar, K., 2020. Pemanfaatan batu apung sebagai material beton ringan, Portal: Jurnal Teknik Sipil, 12(1), 25-32. https://dx.doi.org/10.30811/portal.v12i1. 1826

Pratiwi, S., Prayuda, H., \& Saleh, F. (2016). Kuat tekan beton serat menggunakan variasi fibre optic dan pecahan kaca, Semesta Teknika, 19(1), 55-67. https://doi.org/10.18196/st.v19i1.2033

Prayuda, H., Cahyati, M. D., \& Monika, F. (2020). Fresh Properties Characteristics and Compressive Strength Fiber SelfComapcting Concrete Incorporated with Rice Husk Ash and Wire Steel Fiber, International Journal of Sustainable Construction Engineering and Technology, 11(1), 290-299. https://publisher.uthm.edu.my/ojs/index. php/IJSCET/article/view/6271

Rahamudin, R. H., Manalip, H., \& Mondoringin, H. (2016). Pengujian Kuat Tarik Belah dan Kuat Tarik Lentur Beton Ringan Beragregat Kasar Batu Apung dan Abu Sekam Padi Sebagai Subtitusi Parsial Semen, Jurnal Sipil Statik, 4(3), 225-231. https://ejournal.unsrat.ac.id/index.php/js s/article/view/11623

Song, P. S., \& Hwang, S., (2004). Mechanical properties of high-strength steel fiberreinforced concrete. Construction and Building Materials, 18(2004), 669-673. https://doi.org/10.1016/j.conbuildmat.20 04.04.027

Thomas, J., \& Ramaswamy, A., (2007). Mechanical Properties of Steel FiberReinforced Concrete. Journal of Materials in Civil Engineering, 19(5), 385-392.

https://doi.org/10.1061/(ASCE)08991561(2007)19:5(385)

PENULIS:

As'at Pujianto

Program Studi Teknik Sipil, Fakultas Teknik, Universitas Muhammadiyah Yogyakarta.

Email: pujiantoasat@umy.ac.id

Restu Faizah

Program Studi Teknik Sipil, Fakultas Teknik, Universitas Muhammadiyah Yogyakarta.

Email: restufaizah@umy.ac.id

Dodi Agusto Wijaya

Program Studi Teknik Sipil, Fakultas Teknik, Universitas Muhammadiyah Yogyakarta.

Email: dody.agusta.2012@ft.umy.ac.id

Junaidi Abdurazak

Program Studi Teknik Sipil, Fakultas Teknik, Universitas Muhammadiyah Yogyakarta.

Email: junaidi.abdurajak.2012@ft.umy.ac.id

Hakas Prayuda

Program Studi Teknik Sipil, Fakultas Teknik, Universitas Muhammadiyah Yogyakarta.

Email: hakasprayuda@umy.ac.id

Hendy Wijaya

Program Studi Sarjana Teknik Sipil, Fakultas Teknik, Universitas Tarumanegara.

Email: hendyw@ft.untar.ac.id 